\title{
Um vírus com DNA da globalização: o espectro da perversidade
}

Un virus avec le DNA de la mondialisation : le spectre de la perversité

Un virus con $A D N$ de la globalización: el espectro de la perversidad

A virus with DNA from globalization: or the specter of perversity

\section{Denis Castilho}

\section{(2) OpenEdition}

\section{Journals}

\section{Electronic version}

URL: http://journals.openedition.org/espacoeconomia/10332

DOI: 10.4000/espacoeconomia.10332

ISSN: 2317-7837

\section{Publisher}

Núcleo de Pesquisa Espaço \& Economia

\section{Electronic reference}

Denis Castilho, «Um vírus com DNA da globalização: o espectro da perversidade », Espaço e Economia [Online], 17 | 2020, Online since 06 April 2020, connection on 21 April 2020. URL : http:// journals.openedition.org/espacoeconomia/10332; DOI : https://doi.org/10.4000/espacoeconomia. 10332

This text was automatically generated on 21 April 2020.

(c) NUPEE 


\section{Um vírus com DNA da globalização: o espectro da perversidade}

Un virus avec le DNA de la mondialisation : le spectre de la perversité

Un virus con $A D N$ de la globalización: el espectro de la perversidad

A virus with DNA from globalization: or the specter of perversity

\section{Denis Castilho}

1 A sobreposição de dois mapas, o primeiro disponibilizado pelo Flightradar $24^{4}$, site que rastreia o transporte aéreo mundial, e o segundo pela plataforma da Universidade Johns Hopkins ${ }^{5}$, que atualiza em tempo real o número de casos confirmados de Covid-19, revela a geografia do novo coronavírus. 
Figura 1: Fluxo aéreo mundial (dez. 2019) e casos confirmados de Covid-19 (mar. 2020)

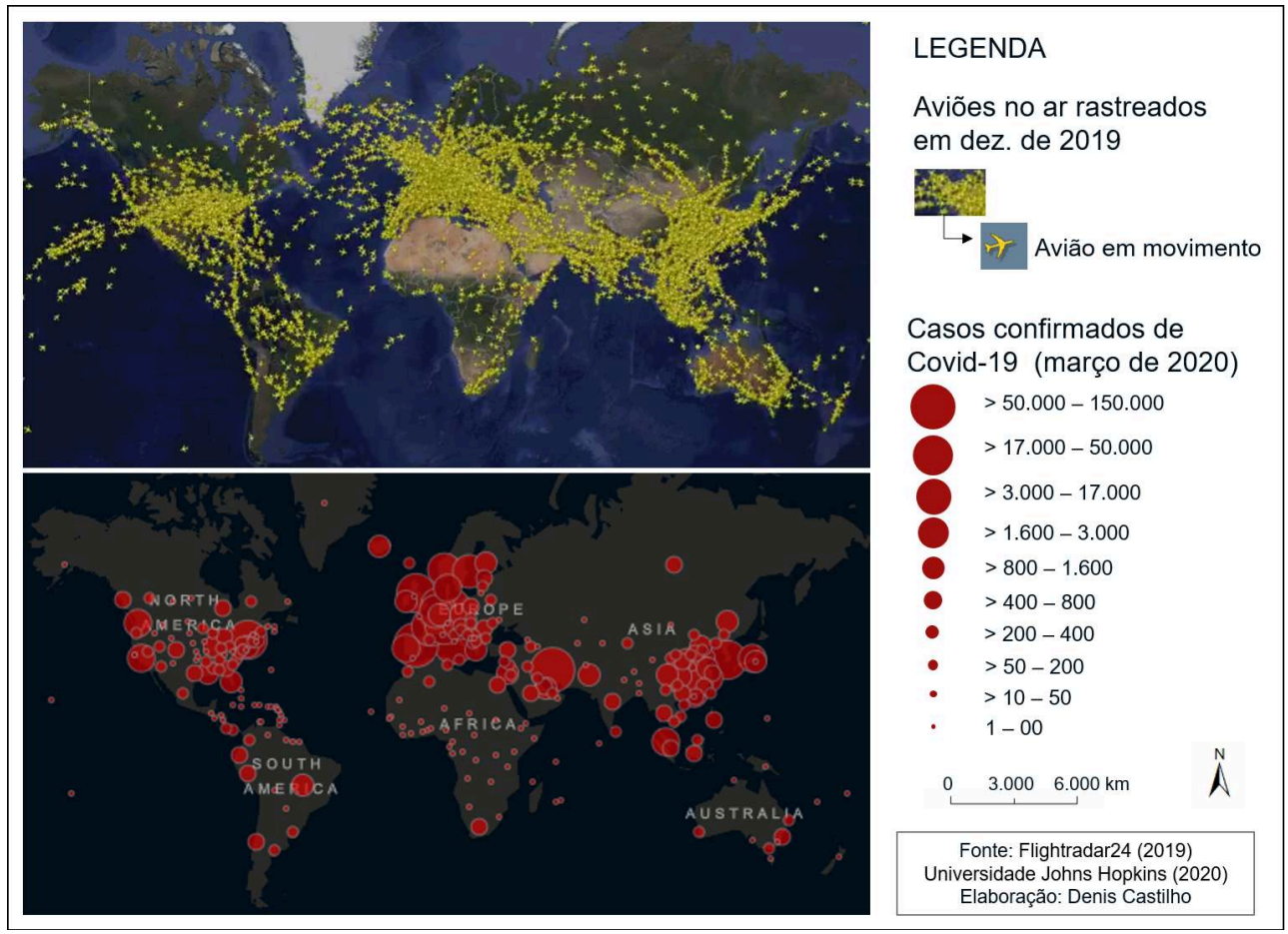

2 É impressionante como essa geografia se confunde com os principais fluxos da economia mundial. Não é exagero, portanto, reiterar a metáfora de que se trata de um vírus urbano, das redes - aquele que, apesar de não se constituir biologicamente como adenovírus, é tributário da modernização contemporânea e, por isso, carrega figurativamente o DNA da globalização. É por isso que em seu gene, há uma perversidade que antecede sua própria natureza epidêmica. Compreendê-la demanda considerar especialmente o tipo de sociedade que gestou o vírus, mas que se revela profundamente incapaz de enfrentá-lo.

\section{Um vírus urbano e das redes}

3 Diferentemente das epidemias que surgiram na China em 2002 e no México em 2009, o novo coronavírus combina rápida expansão e um acesso fácil a diferentes pontos do globo, o que se explica pela posição da China na atual economia mundial e pelas redes de conexões aéreas que terminaram por impulsionar a difusão do vírus.

4 O novo coronavírus também se comporta de maneira quase "perfeita" para um contexto explosivo de expansão. Primeiro, porque age em silêncio na maioria dos casos. Muitos portadores, por não apresentarem sintomas ou sinais de infecção, exprimem elevado potencial de contaminação em um cotidiano carregado de pessoas desprevenidas. Mesmo em países onde a epidemia chegou mais tarde, esse "silêncio" contribuiu com a propagação.

5 Segundo, porque houve (e ainda há), sobretudo, a irresponsabilidade e demora das autoridades na aplicação de medidas de contenção. Quando alguns países emitiram alertas da Organização Mundial de Saúde (OMS), milhares de pessoas contaminadas já estavam em circulação. No Brasil, mesmo com a contenção e o toque de recolhimento decretado em algumas cidades, o vírus já estava presente nas rotas do poder e nos 
condomínios nobres de cidades como São Paulo, Brasília e Rio de Janeiro. Neste país, a situação revela-se ainda pior em meio a uma infraestrutura de saúde aquém das demandas rotineiras e de um baixíssimo estoque de testes, o que torna o número de casos confirmados muito inferior ao número de casos reais.

o baixo monitoramento é um problema grave porque o enfrentamento do vírus exige a quebra das redes de contágio. Identificar os infectados, nesse sentido, torna-se medida estratégica para o retardamento temporal da epidemia. Caso medidas como essa não sejam levadas a sério, a contaminação atinge seu pico em um curto espaço de tempo e empurra o sistema de saúde inevitavelmente para o colapso.

7 Conforme o portal nCov2019.live ${ }^{6}$, o número de casos confirmados já soma $342 \mathrm{mil} \mathrm{em}$ todo o mundo (até 22 de março). Chama atenção a situação da Itália, que tem 59.138 casos confirmados e o maior número de mortes, 5.476. Poucos dias de atraso na aplicação de medidas de contenção amplificaram o colapso nesse país e a própria curva temporal da doença. Isso significa que as medidas de contenção, ao contrário do que dizem muitos empresários e líderes políticos, podem minimizar até mesmo as implicações da epidemia na economia.

8 Um estudo realizado por Ferguson et al. (2020) mostra a eficiência de medidas de saúde pública destinadas a reduzir as taxas de contágio. Segundo os autores, as intervenções devem combinar estratégias de lentidão da expansão do vírus, que ajudam a reduzir a sobrecarga do sistema de saúde, e de supressão, que visam reverter o crescimento epidêmico. Destacam também que a identificação, o controle e isolamento caseiro de casos suspeitos, a quarentena domiciliar e o distanciamento social dos idosos e indivíduos de grupos de risco podem reduzir o pico da demanda de assistência médica em até dois terços e o número de mortes pela metade.

9 No Brasil, já são 1.546 casos e 25 mortes (em 22 de março), apenas 25 dias depois do primeiro caso confirmado. A ascendência da curva que registra os casos não deixa dúvidas do caos que se anuncia. É por isso que a cartografia do vírus irá mudar. De uma espacialização que se confunde com as principais rotas aéreas, o novo coronavírus agora aterrissa no cotidiano das cidades e mira as periferias.

\section{O vírus alcança os pobres, e agora?}

10 O vírus da geopolítica, aquele que viajou de avião, agora alcança os lugares e invade o cotidiano dos pobres. Assim como a globalização, o coronavírus também chega às periferias. Nesse ponto, a metáfora se repete, pois em seu DNA germina a perversidade crua, impiedosa, insana.

11 Por mais que alguns vociferem que o barco seja o mesmo, o que nos separa é dramático e tirânico. De um vírus da geopolítica, agora teremos uma verdadeira geografia do caos. Isso porque o vírus que deixou o patrão em berço esplêndido agora se junta a dezenas de outras doenças que já afetavam a saúde da empregada. As duas primeiras mortes registradas no Brasil, de um porteiro de condomínio de luxo e de uma empregada doméstica, demonstram que a proliferação do vírus também traduz um conflito de classe. No mercado informal ou no que Milton Santos (1979) chama de circuito inferior da economia, milhares de trabalhadores estarão impedidos, em boa medida, de exercer a quarentena. Se medidas urgentes não forem adotadas, a fome, os conflitos e a própria epidemia se intensificarão. 

economia. A medida, segundo nota do próprio banco, é consistente com as regras prudenciais internacionalmente recomendadas e tem relação com a manutenção da estabilidade financeira (Oliveira, 2020). É nesse cenário que o vírus chega aos pobres: enquanto milhares de brasileiros não possuem saneamento básico; enquanto mais de dez milhões de pessoas vivem com míseros 51 reais ao mês, conforme pesquisa divulgada pelo Instituto Brasileiro de Geografia e Estatística (IBGE, 2019); enquanto famílias inteiras não têm sequer sabonete para higienizar as mãos, montantes públicos são despejados nos bancos e isenções são concedidas a centenas de grupos corporativos. A prevalência do mercado financeiro e do dinheiro em estado puro, conforme nos ensina Milton Santos (2007), deixa as pessoas como elementos residuais. redes modernas. A calamidade e as ameaças resultam de um agravo social que se sustenta no autoritarismo e na miséria programada. É por isso que o vírus não atinge a todos de maneira igual - longe disso. O DNA que ele carrega não é estranho ao que já acomete milhares de brasileiros, nem a incapacidade deliberada de lidar com toda a adversidade que ele traz.

\section{Que lições podemos tirar?}

18 Por um lado, os agentes do mercado financeiro já planejam pressões, chantagens e artifícios para tramar reformas e acesso a ativos. $O$ trabalhador, em contrapartida, será ainda mais punido em nome de um jogo "contaminado", perverso e que mata mais que 
qualquer vírus. Formas de produção menos intensivas tomarão corpo, mas com implicações ainda mais sérias para o emprego, conforme alerta David Harvey (2020).

Por outro lado, a arena poderá estar mais nítida. Tendo clareza disso, as bases, sendo forjadas no livre acordo, na livre-iniciativa e no protagonismo, poderão insurgir. Como escreve Jorge Luiz Barbosa (2020), "as organizações da sociedade civil, os trabalhadores da saúde e movimentos sociais precisam ser reconhecidos e afirmados como atores fundamentais para a criação de uma ampla agenda de proteção e cuidados às populações e territórios mais vulneráveis".

O cuidado deve ser estendido à sociedade em geral. Mas não se pode perder a dimensão da fragilidade imediata e evidente, diz Barbosa (2020). "As favelas e periferias precisam de uma quarentena imediata de serviços, bens e equipamentos que permitam enfrentar o contágio em série que as ameaça gravemente".

21 O avanço do vírus é mais rápido do que nossas previsões, evidentemente. Trata-se de um turbilhão que corta o cotidiano, mas não necessariamente nossos desígnios. No meio das lições, haverá aprendizado capaz de mudar o rumo das coisas? Resta-nos perguntar se, a partir dessas lições, ficará patente a necessidade de um sistema de saúde verdadeiramente público e coletivo, reflexão que perpassa o necessário reconhecimento e defesa do SUS. Ganhará força a luta contra o papel parasitário das corporações que dominam a produção de medicamentos e bloqueiam o desenvolvimento de medidas preventivas? A democratização radical de serviços básicos e a premissa da solidariedade estarão reputadas como artifícios de convivência, de desenvolvimento e de equidade?

Em diversas cidades contaminadas pelo vírus, voluntários mobilizam-se para ajudar desabrigados, idosos e grupos de risco. Associações autogeridas mobilizam-se em todo o mundo. A Cruz Vermelha tem atuado em diversas frentes literalmente abandonadas pelo Estado. Em abrigos de países como Canadá, Espanha, Argentina e Brasil, o voluntarismo também mostra sua grandeza. Em Barcelona, todos os dias, às 20 horas, moradores do tradicional bairro de Sant Antoni saem em suas sacadas para aplaudir os trabalhadores da saúde. Esse gesto, ao se repetir em centenas de cidades de todo o mundo, revela um importante sentimento de reconhecimento e de alteridade.

Em Vitória, no Centro Municipal de Educação Infantil João Pedro de Aguiar, mães de alunos, depois que as aulas foram suspensas, fazem vaquinha para ajudar o pipoqueiro. Outras inúmeras ações circulam em cidades como Aracaju, Fortaleza e Rio de Janeiro via redes sociais, para angariar recursos e gêneros alimentícios para pessoas em situação de rua. Em Goiânia, dez cooperativas de catadores, por meio do Movimento Nacional dos Catadores de Materiais Recicláveis (MNCR), já se mobilizam para buscar apoio a trezentos catadores, muitos dos quais idosos e pertencentes a grupos de risco.

São inúmeras as ações baseadas na livre-iniciativa e no voluntarismo. E assim, mesmo diante da demora e/ou da ineficiência do Estado, mesmo diante de governos inertes e muito mais preocupados com a situação dos bancos, pessoas de todo o mundo entram em ação, dão vida à solidariedade e aproximam-se do outro mesmo em circunstâncias que geram pânico e egoísmo.

25 A solidariedade mostra um importante germe de superação em uma sociedade que se construiu sob o prisma do egoísmo e da competitividade (justo essa que torna a epidemia ainda mais letal). Em vista disso, as lições que se anunciam poderão revelar um antídoto muito mais eficaz: aquele que revela e luta contra a principal origem do 
caos, que se organiza e edifica uma nova consciência baseada no protagonismo. Contudo, seja nessa ou nas próximas epidemias, seja em seus intervalos, não desmantelar o DNA que antecede o vírus é o mesmo que naturalizar o espectro da perversidade e a fatídica degeneração de um mundo em coma.

\section{BIBLIOGRAPHY}

BARBOSA, Jorge Luiz. Uma quarentena de direitos para as favelas e as periferias! Rio de Janeiro: Observatório de Favelas, 2020 (mimeo).

BARROS, Arisia. "Moça, às vezes nós não tem água nem pra tomar banho todo dia, imagina lavar as mãos toda hora”. Cada Minuto, 13 mar. 2020. Disponível em: https://bit.ly/2wqDn1S. Acesso em: 21 mar. 2020.

FERGUSON, Neil M. et al. Impact of non-pharmaceutical interventions (NPIs) to reduce COVID-19 mortality and healthcare demand. 16 March 2020. Disponível em https://spiral.imperial.ac.uk: 8443/handle/10044/1/77482. Acesso em: 21 mar. 2020.

FLIGHTRADAR24. Disponível em: https://www.flightradar24.com/17.78,3.74/2. Acesso em: 22 mar. 2020

HARVEY, David. Política anticapitalista em tempos de coronavírus. Tradução de Cauê Seigner Ameni. Jacobin Brasil, 21 mar. 2020. Disponível em: https://jacobin.com.br/2020/03/politicaanticapitalista-em-tempos-de-coronavirus/. Acesso em: 21 mar. 2020.

INSTITUTO BRASILEIRO DE GEOGRAFIA E ESTATÍSTICA (IBGE). Renda do trabalho do $1 \%$ mais rico é 34 vezes maior que da metade mais pobre. Agência IBGE Notícias, 16 ago. 2019. Disponível em: https://bit.ly/2UcEwTK. Acesso em: 21 mar. 2020.

OLIVEIRA, Kelly. Banco Central injeta R\$ 135 bilhões na economia. Agência Brasil, 20 fev. 2020. Disponível em: https://bit.ly/39crr1f. Acesso em: 21 mar. 2020.

SANTOS, Milton. O espaço dividido: os dois circuitos da economia urbana dos países subdesenvolvidos. Rio de Janeiro: Francisco Alves, 1979.

SANTOS, Milton. Por uma outra globalização. 14. ed. Rio de Janeiro: Record, 2007.

UNIVERSIDADE JOHNS HOPKINS. Coronavirus Resource Center. Disponível em: https:// coronavirus.jhu.edu/. Acesso em: 22 mar. 2020.

\section{NOTES}

1. Disponível em: https://www.flightradar24.com/17.78,3.74/2. Acesso em: 22 mar. 2020.

2. Disponível em: https://coronavirus.jhu.edu/. Acesso em: 22 mar. 2020.

3. Disponível em: https://www.flightradar24.com/17.78,3.74/2. Acesso em: 22 mar. 2020. 
4. Disponível em: https://www.flightradar24.com/17.78,3.74/2. Acesso em: 22 mar. 2020.

5. Disponível em: https://coronavirus.jhu.edu/. Acesso em: 22 mar. 2020.

6. Disponível em: https://ncov2019.live/. Acesso em: 22 mar. 2020.

\section{ABSTRACTS}

The Overlap the two maps, the first available for Flightradar $24^{3}$, website that tracks the worldwide air transport, and the second for Johns Hopkins University website, that updates in real times the number of confirmed cases from Covid-19, reveals the geography of new coronavirus.

A sobreposição de dois mapas, o primeiro disponibilizado pelo Flightradar $24^{1}$, site que rastreia o transporte aéreo mundial, e o segundo pela plataforma da Universidade Johns Hopkins ${ }^{2}$, que atualiza em tempo real o número de casos confirmados de Covid-19, revela a geografia do novo coronavírus.

Disponibles respectivement chez Flightradar 24 et chez John Hopkins University, la superposition de la carte des transports aériens mondiaux et des chiffres de la Covid-19 révèlent la géographie de la pandémie.

Covid-19, globalización, pandemia, mapas, geografía

La superposición de dos mapas, el primero puesto a disposición por Flightradar24, un sitio que rastrea el transporte aéreo mundial, y el segundo por la plataforma de la Universidad Johns Hopkins, que actualiza en tiempo real el número de casos confirmados de Covid-19, revela la geografía del nuevo coronavirus.

\section{INDEX}

Mots-clés: Covid-19, mondialisation, pandémie, cartes, géographie.

Palavras-chave: Covid-19, mundialização, pandemia, mapas, geografia

Keywords: Covid-19; mundialization; pandemic; maps; geography.

\section{AUTHOR}

\section{DENIS CASTILHO}

Doutor em geografia e professor dos cursos de graduação e pós-graduação do Instituto de Estudos Socioambientais da Universidade Federal de Goiás. E-mail: deniscastilho@hotmail.com 